\title{
高導電率で可溶性ポリアニリンの合成 \\ Preparation of Highly Conductive Soluble Polyaniline
}

\author{
倉 本 憲 幸* \\ Noriyuki KURAMOTO
}

\section{1. 導電性高分子の発展}

2000 年度の白川先生のノーベル化学賞をきっかけとし て導電性高分子は, 基礎研究の段階加実用段階に入って きた。導電性高分子は電気を導く性質を有する高分子とし て知られるが, それ以外にも多種多様な性質機能を持つ機 能性高分子であある。実用的にも魅力ある材料であり, 最 初に二次電池の正極材料として実用化され, 現在では有機 EL 素子からプラスチックトランジスターまで多くの実用 可能性が指摘されている。

導電性高分子の実用化に関しては, ポリアセチレンを中 心として早くから種々の応用が提案されてきたが, ポリア セチレンの場合は共役二重結合が空気酸化を受けやすく不 安定であるため実用化までに至っていない。これに対して 芳香族系の導電性高分子, ポリチオフェン, ポリピロール, ポリアニリンなどは, 空気酸化に対する安定性に優れてお り, 導電性の経時変化が少ないことから, より実用化に適 した材料として既に実用化されて市場に供されている。

空気安定性に優れたポリピロールを用いた帯電防止材が 市販され，またアルミコンデンサーの固体電解質として用 いてチップ型固体電解コンデンサーが開発されている。こ の技術は電気化学協会賞を受賞しており, 電解液を用いる コンデンサーに比べて大容量でかつ高周波数領域において 良好な特性を示す固体コンデンサーを作成することが出来 て，全固体型であるのでコンパクトとなる。

同様に最近ではポリチオフェン誘導体がコンデンサー用 途に開発されており, ポリ（3,4-エチレンジオキシチオ フェン) がバイエルによってバイトロンという商品名で販 売されている。このポリマーを固体電解質に用いたコンデ

* 山形大学大学院理工学研究科 生体センシング機能工学専攻 山形県米沢市城南 4-3-16 干992-8510

Graduate School of Science and Engineering, Yamagata University

4-3-16, Jonan, Yonezawa, Yamagata, 992-8510 Japan
ンサーへの用途が広がっている。水系で酸化重合により合 成が行われており, 特にコンデンサー用途に用いられてい る。

多くの導電性高分子の中でポリアニリンは最む実用化に 近い位置にある導電性高分子である。ポリアニリンはブリ ヂストンによりポリマーバッテリーとして最初に二次電池 の正極材料として実用化された歴史を持ち，また既に現在 帯電防止材料や防錆塗料として実用化され市販されている 導電性高分子である。実用にとって大きなファクターであ るコストの点で安価であり, 大量合成が容易であって空気 安定性にも優れており, 現在では加工性と導電性す良好と なって, 実用化にとって必要な条件を有している。ポリア ニリンはポリチオフェンやポリピロールなどと異なり，プ ロトン付加によってその導電性が大きく变化する特異な性 質を有している。その特異な電気化学特性と安定した導電

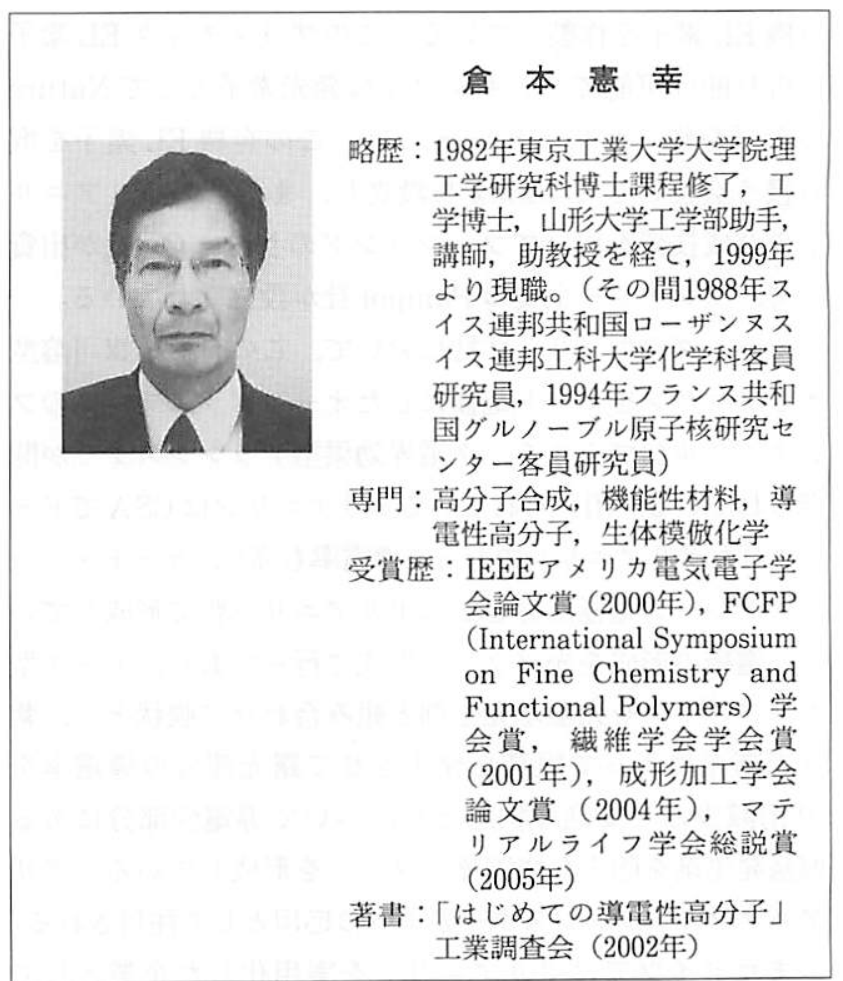


性により, 二次電池の正極材料, エレクトロクロミック材 料, 各種センサー材料, 帯電防止塗料, 電磁波シールド材 料, 光記録素子, 人工筋肉材料, 防錆塗料, エレクトロレ オロジー流体用分散剤など電気・電子・機械の幅広い分野 において応用が検討されている1)。

導電性高分子の欠点は剛直であるため不溶不融で加工性 に欠けている点であり, ポリアニリンについてあ応用面が 限られてきた。しかしポリアニリンを塩基処理した状態で は $\mathrm{N}$-メチルピロリドンに可溶となり, 絶縁状態ながらポ リアニリン膜を形成出来ることが日東電工において見出さ れている。この塩基状態のポリアニリンの膜は酸処理によっ て導電状態に変化し，ポリアニリンの塩基性絶縁膜を形成 した後で酸処理を施すことで，導電性ポリアニリン膜を形 成した。

ついで Cao と Heeger らによってポリアニリンの加工 性と導電性を大きく向上させる合成法が開発され, 導電性 を保ったままで各種有機溶媒に溶解するポリアニリンが合 成された。無機酸中で合成したポリアニリンから, 塩基処 理により塩基状態のポリアニリンを合成し, ついで機能性 ドーパントと呼ばれる CSA（カンファースルホン酸）や DBSA（ドデシルベンゼンスルホン酸）を加えて取り込ま せることで, $\mathrm{m}$ ークレゾールやキシレンに可溶となる有機 溶媒可溶型ポリアニリンが得られる。彼らはポリアニリン を有機 EL 素子のホール輸送材として陽極側に用いて有機 EL 素子を作成している。溶液からキャスト法によりポリ アニリン導電性膜を $\mathrm{PET}$ 基盤上に作製し，ついでポリア ニリン膜上にポリパラフェニレンビニレン誘導体を溶液か らキャストして発光層とし，その上に金属電極を蒸着して， 有機 EL 素子を作製している。このプラスチック EL 素子 は折り曲げ可能でフレキシブルな発光素子として Nature の表紙を飾った ${ }^{2)}$ 。Heeger らは，この有機 EL 素子を取 り扱う会社としてUniax を設立し，またこのポリアニリ ンの合成技術を用いてフィンランドの Neste Oy 社が出資 して, ベンチャー企業の Panipol 社が設立されている。 オランダのフィリップ社において，この有機溶媒可溶型 ポリアニリンをゲート電極にしたオールプラスチックのフ レキシブルなプラスチック電界効果型トランジスターが開 発されている。用いられているポリアニリンは CSA でドー プされたポリアニリンであって導電率も高く, ゲート・ソー ス・ドレーン電極部分をこのポリアニリン膜で形成してい る。電極の形成を光パターン形成で行っており，ドープ型 ポリアニリンを光塩基発生剤と組み合わせて膜状とし, 紫 外光露光によって塩基を発生させて露光部分の導電率を 10 桁減少させて絶縁状態とし, ついで尊電性部分にある 塩基発生剤を除去して電極パターンを形成している。ポリ アニリンのトランジスター素子への応用として注目される。 またドイッではポリアニリンを実用化した企業として
Ormecon 社があり, 早くから溶媒分散型のポリアニリン を企業化し，有機酸をドーパントに用いて有機溶媒に高度 に分散するポリアニリンを合成し，この溶媒分散型ポリア ニリンを主として防錆染料として市場に供してきた。金属 表面にポリアニリンを塗布することで，金属とポリアニリ ンとの間の酸化還元反応によって, 金属表面に酸化保護膜 が形成され防錆効果を発現する。既に錆を生じている場合 の防錆塗料用には Correpair として商品化されており， 1. 錆落とし, 2. 錆止め, 3. 表面コート材の 3 点セットで販 売しており，ポリアニリンは 2 の錆止め塗料の中に含まれ ている。また金属表面を保護して用いる防錆塗料用に Coppasive という商品名でポリアニリンを販売している。 さらに各種の導電材料として Ormecon という商品名で販 売しており，プリント配線基板用や帯電防止用など各種の 導電性用途に用いられるポリアニリン製品を販売している。 現在はこの分散型ポリアニリンを導電性材料として応用範 讲を拡大し，プリント基板形成における工程を省略出来る ことからプリント基板形成への応用を見込んでいる。また 日本においても提携会社と結んでポリアニリンを用いた事 業の展開を図っている1)。

このようにポリアニリンを初めとして導電性高分子は初 期における電解重合を中心とした特性評価の段階から，今 日では実用化されて実際に電気電子の分野で用いられる段 階に入っており，ますます㛜しい評価のむとに競争を迫ら れる段階に達してきた。したがって少しであ優位性のある 導電性高分子が実用上有利となる。

\section{2. ポリアニリンの構造と機能について}

ポリアニリンはポリチオフェンやポリピロールなどと異 なり, プロトン付加によってその導電性が大きく変化する 特異な性質を有している。図 1 にアニリンの酸化カップリ ングからポリアニリンの形成までを示したが, 酸化反応で ある電子の引き抜き反応は, 化学酸化試薬や電気的に正電 極を用いて行われる。最初にアニリンの窒素原子にある非 共有電子対から電子が引き抜かれて, ラジカルカチオンが 形成される。この窒素上のラジカルカチオンはベンゼン環 中にあるパイ電子と共鳴しており三種の共鳴混成体が得ら れる。この中でパラ位にラジカルを有する共鳴構造体と窒 素ラジカルとでカップリングして頭尾結合が形成され, 脱 プロトン化して，二量体が形成される。さらに同様にカッ プリングを繰り返して, アニリンの三量体, 四量体, 五量 体，オリゴマーとなって重合が進んで行き，最終的にポリ アニリンが形成されると考えられている。

図 2 にはポリアニリンの構造を示したが, 四量体で一つ の構造単位として考えられている。酸化重合により合成直 後のポリアニリンには酸成分がドーパントとして入り込ん で静電的に結合し，ハーフ酸化状態の導電体が得られる。 
<smiles>Nc1ccccc1</smiles>

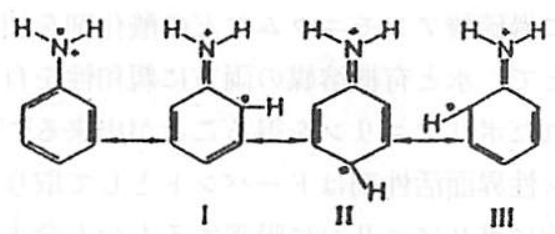

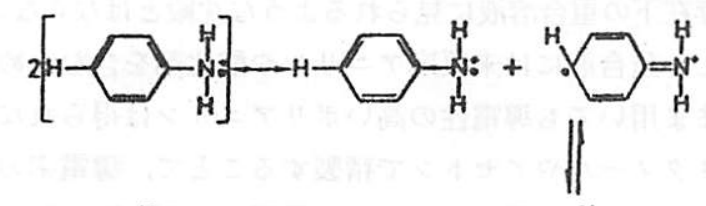<smiles>[NH3+]C1C=CC([AlH2]c2ccc(C=CCNc3ccc(Nc4ccccc4)cc3)cc2)C=C1</smiles>

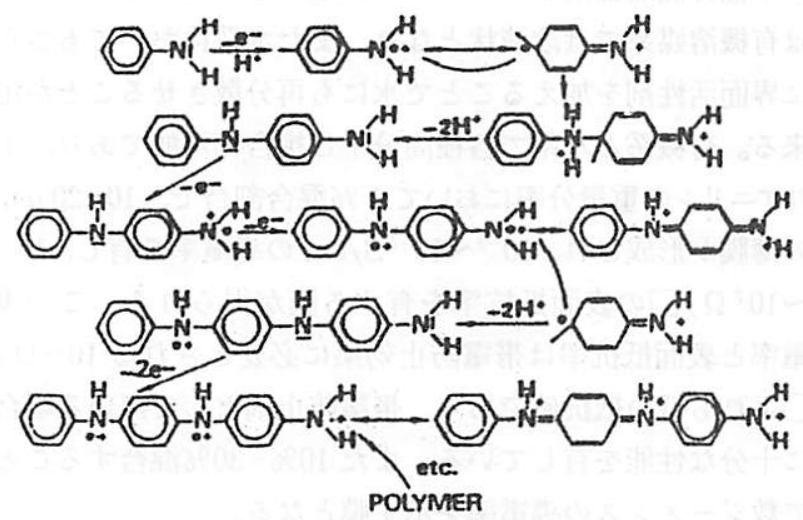

図 1
この状態のポリアニリンは緑色のエメラルド色をしており, エメラルジン塩と呼ばれて導電性を示す。このエメラルジ ン塩をアルカリ溶液中で処理すると, 無機酸の塩から無機 酸が外れて脱ドープ状態となり, 色も緑色から青色となり, エメラルジン塩基と呼ばれる絶縁性のポリアニリンとなる。 また電子状態を变化することも出来て, エメラルジン塩の 八ーフ酸化状態から還元すると, 完全還元状態のポリアニ リンとなる。無色であるため無色を意味するロイコ体の名 前がついており, ロイコエメラルジンと呼ばれている。こ の完全還元状態のポリアニリンのロイコエメラルジンは, 空気中では不安定であり, 空気中の酸素によって容易に酸 化されて, ハーフ酸化状態のエメラルジンとなる。またハー フ酸化状態のエメラルジンは, さらに酸化を押し進めるこ とあ出来て, 完全酸化状態のペルニグラニリンが得られる。 この完全酸化状態のペルニグラニリンは構造中に発色団で あるイミ゙ンシキノン構造を多く含んでおり, 色は黒色となっ て黒色顔料のアニリンブラックの色に近くなる。このペル ニグラニリンあ絶縁体であって, ポリアニリンにおいては, ハーフ酸化状態で酸性塩となっているエメラルジン塩のみ が導電性を示す ${ }^{1)}$ 。

ポリアニリンに限らないが, 導電性高分子の実用上の問 題点は, どんな溶媒にも溶解しない（不溶）し，熱を加え ても溶融しない（不融）という性質であり, 他の高分子と 同様に塗布してフィルムとして用いることや, 成形加工し て用いることが出来ないため, 用途が大幅に制限されてき た。一般に化学酸化重合で得られるポリアニリンは粉末状 であり,フィルムとして得ることが難しいため, 電極上に フィルム状で得られる電気化学装置を用いた電解重合を主 体にした研究が行われてきた。アニリンの電解重合系にお いて，アニオン性高分子やアニオン性界面活性剤を加える 之, 電解重合速度が加速されて表面構造む大きく変わって くる。アニオン性高分子としてポリビニル硫酸ナトリウム

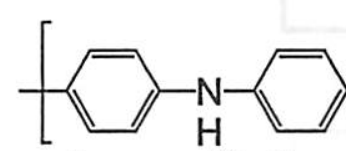

Leucoemeraldine Base<smiles>Cc1ccc(Nc2ccc(C(C)(C)C)cc2)cc1</smiles>

Emeraldine Base<smiles>CNc1ccc(Nc2ccc(N3CCN3)cc2)cc1</smiles>

邹䌐性<smiles>Cc1ccc(C(C)(C)C)cc1</smiles>
酸化

(blue) 還元

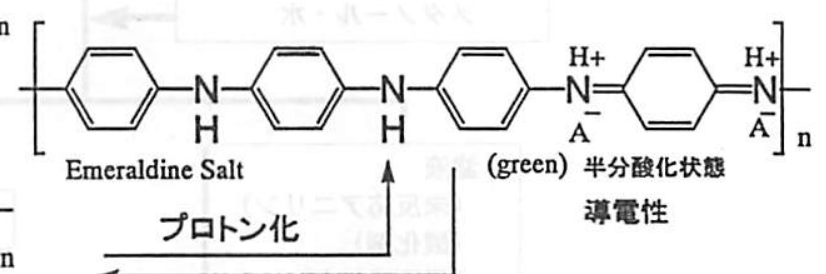

アルカリ処理

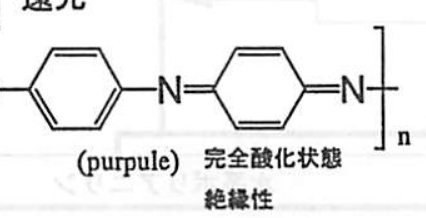

図 2 導電性高分子「ポリアニリン」 
を用い，アニオン性界面活性剤としてドデシル硫酸ナトリ ウムやドデシルベンゼンスルホン酸を用いて重合を行った 場合において, 重合速度が加速されて構造も違った形態に なることが分かっている3)。

モノマーであるアニリンの酸化電位は $780 \mathrm{mV}$ 付近（基 準電極が飽和カロメル電極の時）にあるのに対して，ア二 オン性物質を加えた系では $650 \mathrm{mV}$ といった低電位に移行 する。アニオン性物質を加えることで，塩基であるアニリ ンと結合してアニオン性物質とアニリンの塩が形成されて, 結果的にアニリンの酸化重合電位が下がることが分かった。

\section{3. ポリアニリンのドーパントとしてのアニオン性} 界面活性剂

我々は界面活性剤とアニリンの組み合わせによる化学酸 化重合によって, 有機溶媒に高分散して可溶状態となるポ リアニリンの合成法を見出した ${ }^{4)}$ 。アニオン性, 中性, カ チオン性のそれぞれの界面活性剤を用いたが，アニオン性 界面活性剤を重合系に用いた系だけが，均一で水溶液状の 重合液を得ることが出来た。この重合はミセル化学酸化重 合法であるが，ラジカル重合における高分子の合成方法で ある乳化重合と同様である。界面活性㓮などを乳化剈に用 いて油溶性のモノマーを水中に乳化させて行うラジカル重 合があるが, ポリアニリンの重合系むこのラジカル乳化重 合に似ており，用いる界面活性剤の濃度が高くなると，得 られるポリアニリンの粒子経む小さくなるという結果とな る。また得られたポリアニリンは $\mathrm{pH}$ 変化に対してあ安定 であり, 通常無機酸の存在下で得られるポリアニリンに比 較して, 高 $\mathrm{pH}$ の領域までエメラルジン塩の状態を保って おり, $\mathrm{pH}$ 安定性が高いということが分かった。これはア ニオン性界面活性剤がポリアニリンにドーパントとして取 り込まれて疎水性相互作用によりポリアニリンとの結合が
強固になっており, 脱ドーパントが起こり難くなって, 結 果的に高 $\mathrm{pH}$ 領域まで導電性のあるポリアニリン塩の状態 が保たれる。図 3 に示すように，アニリンは塩基であり， アニオン性物質と $1: 1$ で反応させるとアニリンの塩を形 成する。この時にアニオン性界面活性剤を用いると, ア二 リンのアニオン性界面活性剤の塩が形成されるが，このア ニリン塩に過硫酸アンモニウムなどの酸化剤を加えて重合 を行うことで, 水と有機溶媒の両方に親和性を有する両親 媒性に優れたポリアニリンを得ることが出来る ${ }^{5 \sim 9)}$ 。

アニオン性界面活性剤はドーパントとして取り込まれる が，物理的にポリアニリンに吸着するものあ含まれる。得 られる重合溶液は均一であって水を加えると希釈され, 無 機酸存在下の重合溶液に見られるような沈殿とはならない。 ただし，重合液には未反応アニリンや酸化㓮を含むため， そのまま用いても導電性の高いポリアニリンは得られない が，メタノールやアセトンで精製することで, 導電率の高 いポリアニリンが得られる。この界面活性剤を取り込んだ ポリアニリンは, 有機溶媒系で各種汎用高分子と, また水 系で各種水溶性高分子と複合可能で相溶性に優れており, 含有量が少量でむ高い導電性を示す材料となる。このアニ オン性界面活性剤をドーパントに取り込んだポリアニリン は有機溶媒系では溶液状となり，また水系においてもさら に界面活性剤を加えることで水にも再分散させることが出 来る。有機系と水系で各種高分子と複合化可能であり，ポ リアニリンの重量分率において $1 \%$ 混合割合で， 10-20 $\mu \mathrm{m}$ の薄膜が形成され, $10^{-3} \sim 10^{-5} \mathrm{~S} / \mathrm{cm}$ の導電率を有し, $10^{-5}$ $\sim 10^{7} \Omega$ / 口の表面抵抗率を有する膜が得られる。この導 電率と表面抵抗率は带電防止効果に必要とされる $10^{12} \Omega /$ 口よりも低い抵抗值であり，帯電防止剤として用いる場合 に十分な性能を有している。また $10 \%-30 \%$ 混合すること で数ジーメンスの導電率を示す膜となる。

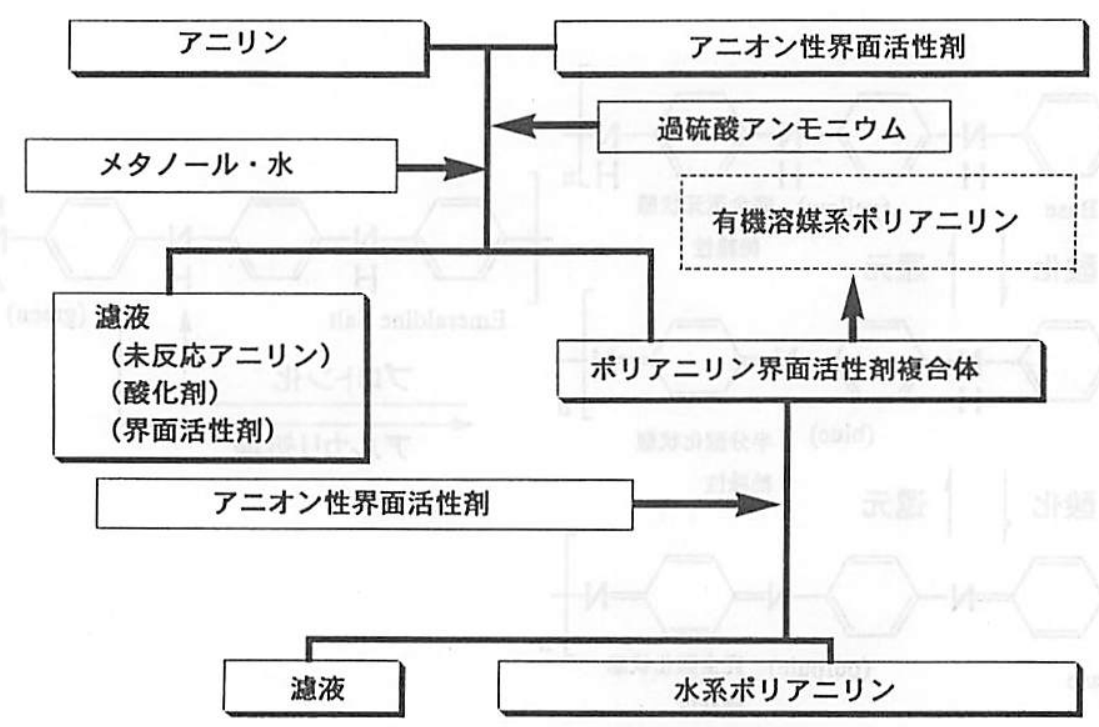

図 3 ポリアニリンとアニオン性界面活性剤複合体の合成 
この重合系の特徴として,

1. 1 段階の重合で簡単に合成できること

2. 水系における水溶性高分子との複合化む可能である こと

3. $10 \%-30 \%$ で数ジーメンスの導電率を示す

4. $1 \%$ 以下の混合比率において数マイクロメートルの 薄膜で, 静電気を防止する帯電防止機能に必要な表 面抵抗率をみたすことがあげられる。

静電気障害は減少するどころかますます増加しており, 新しい産業が生まれ, 新しい製造プロセスが開発されると, そこにまた新しい静電気障害が発生する。技術の高密度化, 軽薄短小化, 高スピード化は, ますます静電気の発生源を 増大させることとなり, 静電気に対して敏感な製品が生み 出される結果となっている。特に高集積度 IC デバイスの 静電気破壊は今日的な問題であり, 静電気を野放しにする と多大な損害が発生する場合むある。静電気破壊は静電気 による回路の破壊で気がつかない内に破壊が進む現象であ る。静電気放電は IC などの電子部品にとって, とても恐 ろしい存在である。

このような静電気による障害を防ぐ上で, 導電性物質と してカーボンブラックを分散させた帯電防止材や, 界面活 性剤を含有して表面を親水性とした帯電防止材が用いられ ているが, カーボンブラックの場合は黒色で透明性が失わ れ, さらに脱離して電子部品を污染するなどの問題, また 界面活性剤の場合は長期間使用すると表面から失われてい

\section{くブリードアゥトの問題が指摘されている。}

アニオン性界面活性剤でドープされたポリアニリンは, 他の高分子との複合化により, 低いポリアニリン含有量に おいて透明で帯電防止機能を備えた導電性を示す材料とな る。アニオン性界面活性剤の技術を用いたポリアニリンを 導電性インクにして PET 表面に印刷して成形したトレイ は, 山梨にある株式会社マルアイより SCS-NEO の商品 名で市場に出されており, 帯電防止材として評価されて用 いられている。特にポリアニリンを用いる大きな特徴は, 薄膜状に出来て透明性が良いこと, 塗布後に成形するが成 形時における追随性が良いこと, 表面抵抗值が安定してい ること, アウトガスの発生がないこと, 優れた表面の耐磨 耗性があることなどがあげられている。

\section{4. 高導電率で可溶性ポリアニリンの合成}

最近, 我々はアニオン性界面活性剤を種々検討した結果, 特に疎水性の高いアニオン性界面活性剤をポリアニリンの ドーパントに用いると, トルエン, ベンゼン, クロロホル ムなどの有機溶媒に可溶性となるポリアニリンが合成出来 る事を見出した ${ }^{10)}$ 。しかも，この疎水性アニオン性界面 活性阂を含むポリアニリンは, 溶解性が高いという特徵の 他に, さらに二次ドーパントを加える事で数百倍すの導電
率の変化, 向上を引き起こす。

この疎水性アニオン性界面活性剤を含んだポリアニリン は, 二次ドーパントを後添加する事でポリアニリンの主鎖 とドーパント間で相互作用して, ポリアニリンの著しい電 子状態の変化をあたらすことが判明した。顕著に現れる特 徵はポリアニリンの導電率の变化と上昇であるが, 同時に 吸収波長が長波長側へシフトして色変化としても現れる。

ポリアニリンの吸収においては, 特徵的なポーラロン状 態に起因するポーラロンバンド吸収帯が $80 \mathrm{~nm}$ 付近に現れ るが, 二次ドーパントを加える事で吸収帯のシフト変化が あたらされる。ポリアニリンの共役鎖長の拡大に伴って起 こる長波長側へのシフトであって, $900 \mathrm{~nm}$ から $2000 \mathrm{~nm}$ にかけての近赤外領域の吸収帯にシフトする。この色変化 を伴って導電率の著しい上昇が起こることから, 共役鎖長 の拡大と導電性に関連性が認められる。

ポリアニリンの共役鎖長は Compact Coil 状態から Extended Coil 状態へと拡張して, 導電率の向上をむたら す。二次ドーパントとして有効なのは $\mathrm{m}$ ークレゾールであ るが, $\mathrm{m}$ ークレゾールは以前よりポリアニリンの良溶媒と して知られており， $\mathrm{m}$ ークレゾール中でのポリアニリンは 鎖長が拡大して，より広がった状態となる。m-クレソー ルが二次ドーパントとして有効なのは, 良溶媒としての 働きと,さらには固体化した時の結晶化の核となってポリ アニリンのより結晶化を促進する効果があるあのと思われ る。

このようなポリアニリンを合成する上で用いたアニオン 性界面活性剤は，コハク酸のジェチルヘキシル誘導体であ る商品名 $\mathrm{AOT}$ (アエロゾル OT) である。AOTを用いて, 溶媒として水及び有機溶媒中において開始剤として過硫酸 アンモニウムを酸化剤にしてアニリンを重合すると, 有機 溶媒に可溶性のポリアニリンを得る事が出来る。

このポリアニリンはベンゼン, トルエン, キシレン, ク ロロホルムなどの疎水性有機溶媒に可溶状態となって濃厚 溶液状態となり, さらにこの系に二次ドーパントとして mークレゾールを添加する事で, $300 \mathrm{~S} / \mathrm{cm}$ 以上の導電率を 示す高導電率ポリアニリンを合成することが出来る。

従来から市販されているポリアニリンはOrmecon 社製 やPanipol 社製のものが知られているが, Ormecon 社の ポリアニリンは導電性高分子は不溶, 不融であるという概 念が基本にあることから，分散させることで作成されてお り粒子分散型である。また Panipol 社のポリアニリンは 1 段階でエメラルジン塩を無機酸性溶液媒体中で合成し, 次 いで塩基によって脱ドープしエメラルジン塩基とする。次 に得られたエメラルジン塩基にカンファースルホン酸など の有機酸を加えて, 後ドープの形で合成される。後ドープ して得られる有機酸をドープしたエメラルジン塩は, Ormecon 社の分散型とは異なっており, 有機溶媒に可溶 
(1) 有機溶剂可溶性(トルエン、キシレン等均一溶液)

(2) 高導電性 $(\backsim 300 \mathrm{~S} / \mathrm{cm})$ 可能。既存最高レベル

(3) 自己造膜性あり。(自己自立性フィルム作成可能)

(4) 安定した導電性

(5) 塗料化容易 (各種コ一ティング剂、ハードコート剂適用可能)

(6) 安価化可能(アニリンモノマーを原料)

スキーム 1 高導電性ポリアニリンの特性

となっている。しかしながら，二段階を経て合成されてお り, また後添加する有機酸であるドーパントも特殊なカン ファースルホン酸が最む導電率が高く, また m-クレゾー ル溶媒から作成される。

今回我々が見出した系は, 一般的なアニオン性界面活性 剤を用いて, 一段階で合成出来るため, さらに簡便に量産 が可能となって実用上大きな利点を有する事となる。

この手法によって得られた可溶性高導電性ポリアニリン の特徵を示すとスキーム 1 のようになり, 有機溶媒への可 溶性と高導電率を併せ持った導電性高分子を得る事が出来 る。しかも二次ドーパントを加えた膜は吸収波長が長波長 側へシフトして, 近赤外領域の吸収へと変化するため, 赤 外線波長のカットフィルターにも使用が可能である。また 二次ドーパントは主鎖の鎖長間に入り込んで橋掛け剤的な 役割をするため, 自己造膜能があって形成された膜は強固 な膜となり機械的強度に優れた膜となる。導電性は通常の 大気下の使用条件では十分安定であり, 長期間安定した導 電率を示す膜となる。このため, 有機溶媒を用いての導電 性塗料を作成する事む可能であって, 高導電率のインクを 作成可能である。
また使用される合成試薬はアニリンを初めとして, 種々 の化学薬品の中間体として良く使用される安価な試薬であっ て，コスト的にも実用的な有利さを備えている。したがっ て, 従来にない導電性と溶解性を生かした新規な用途が見 込まれる事が期待される。導電性を生かした用途から予想 される市場としてクリーンな静電気防止材があり, 想定さ れるユーザーは電子部品製造メーカーの加工工場やクリー ンルームを有する研究所等が予想される。また，想定され る市場として静電気防止材料や電磁波シールド材料等の透 明導電性材料や電極材料として, また導電性繊維や人工筋 肉材料, 及び防錆塗料や活性酸素発生材料などの利用が想 定される。

\section{参 考 文 献}

1）倉本憲幸,「はじめての導電性高分子」，工業調查会， 2002 年.

2) G. Gustafsson, Y. Cao, G. M. Treacy, F. Klavette, N. Colaneri, and A. J. Heeger, Nature, 357, 477 (1992).

3) N. Kuramoto, J. C. Michaelson, A. J. McEvoy, and M. Gratzel, J. Chem. Soc. Chem. Commun, 1990, 1478 (1990).

4) N. Kuramoto, and E. M. Genies., Synthetic Metals, 68, 191 (1994).

5) N. Kuramoto, and A. Tomita., Polymer, 38, 3055 (1997).

6) N. Kuramoto, and A. Tomita., Synthetic Metals, 88, 147 (1997).

7) N. Kuramoto, and K. Teramae, Polym. Adv. Tech, 9, 222 (1998).

8) N. Kuramoto, and Y.. Takahashi, React. Funct. Polym.,, 37, 33 (1998).

9）倉本憲幸, 工業材料，47, 57 (1999).

10) Lee K. S., T.Hino T and Kuramoto N., Chem. Lett., 2007, 340 (2007). 